\title{
Laboratory Findings of Typhoid Fever in Children: Study in a Tertiary Care Hospital
}

\author{
Dr. Amal Kanti Banik ${ }^{1 *}$, Dr. Khokan Chandra Mazumder ${ }^{2}$, Dr. Mrinal Kanti Mondol ${ }^{3}$, Dr. Goury Prava Dhar ${ }^{4}$, Dr.
} Mohammad Shafiqul Alam Chowdhury ${ }^{5}$

${ }^{1}$ Registrar, Department of Paediatrics, Dhaka Shishu (Children) Hospital, Dhaka, Bangladesh

${ }^{2}$ Assistant professor, Department of Paediatrics, Cumilla Medical College, Cumilla, Bangladesh

${ }^{3}$ Assistant professor, Department of Paediatrics, Patuakhali Medical College, Patuakhali, Bangladesh

${ }^{4}$ Faculty, Evolution Health Academy, Miami Garden, Florida-33169,USA

${ }^{5}$ Assistant Professor, Department of Paediatrics, Dhaka Medical College Hospital, Dhaka, Bangladesh

DOI: $10.36347 /$ sjams.2020.v08i10.009

| Received: 13.09.2020 | Accepted: 21.09.2020 | Published: 11.10.2020

*Corresponding author: Dr. Amal Kanti Banik

Abstract

Original Research Article

A case-control type of study was conducted over a period of 6 (Six) months following approval in the Department of Paediatrics, Dhaka Shishu (Children) Hospital, Dhaka, Bangladesh during the period from October 2012 to April 2013. Our aim was to assess laboratory findings of typhoid fever in children in Bangladesh. The sample size for this study was 240 (120 cases and 120 controls). Out of 120 participants in each group 79.2\% cases and 68.3\% controls respondents were mother of the children. In both groups, most of the study participants were from younger age group $\leq 5$ years; $63.3 \%$ of cases and $80.8 \%$ of control. Mean \pm SD of age were $(5.1042 \pm 3.11575)$ for cases and $(3.5951 \pm 2.50218)$ for controls Age distribution of the children was statistically significant where $p$-value was 0.0001 for t-test and 0.01151045 for chi-square $(\mathrm{p}<0.05)$. There was no positive association of different blood group but when each group was individually considered, blood group ' $\mathrm{B}$ ' indicated there may be some positive association (RR $=1.4505, \mathrm{OR}=1.8713$ and $\chi^{2}=4.66, \mathrm{p}=0.030873$ ). Only $3.3 \%$ children in case group and $4.2 \%$ in control group had $\mathrm{Rh}$ negative blood group. Widal test result was positive in $83.3 \%$ of cases; the remaining $16.7 \%$ were found to be Widal negative. The difference was statistically significant $\left(\chi^{2}=18.22, p=0.0001\right.$. Blood culture was done in only $50(41.7 \%)$ participant from the case group; out of them negative culture was obtained in 4 individuals, the difference was statistically significant $\left(\chi^{2}=52.585, \mathrm{p}=0\right.$. $(\mathrm{P}<0.05)$. Typhoid fever has a strong relation with socioeconomic conditions and blood phenotypes.

Keywords: Typhoid fever, blood phenotype ABO, Rh.

Copyright (C) 2020 The Author(s): This is an open-access article distributed under the terms of the Creative Commons Attribution 4.0 International License (CC BY-NC 4.0) which permits unrestricted use, distribution, and reproduction in any medium for non-commercial use provided the original author and source are credited.

\section{INTRODUCTION}

Typhoid fever is a systematic clinical syndrome by certain salmonella organism. It encompasses produced by certain Salmonella typhi, and Para typhoid fever is caused by Salmonella paratyphi[1]. Typhoid fever is rare in industrial countries but continues to be a significant public-health issue in developing countries[2]. A detail study of the disease was presented by Bretonneau (1826) who identified the intestinal lesions. The name of enteric was given by Louis (1829) to distinguish it from typhus fever. Budd (1856) pointed out that the disease was transmitted through the excreta of patients. Elberth (1880) described the typhoid bacillus, and Gaffky (1884) isolated it in pure culture. Its causative role was confirmed by Metchnikoff and Bessedka (1900) by infecting experimentally
[2]. The incidence, mode of transmission and consequences of typhoid fever differs significantly in developed and developing countries. The incidence has decreased markedly in developed countries. In the United States about 400 cases of enteric fever are reported each year giving an annual incidence of less than $0.2 \%$ per $1,00,000$ population which is similar to that in western, Europe and Japan[3].

Typhoid fever is transmitted via the faecal oral route or urine. This may take place directly through soiled hands, contaminated with faeces or urine of cases or carrier or indirectly by ingestion of contaminated water, milk, food or through flies [4]. Typhoid fever is an important cause of morbidity and mortality in many developing countries. In 2000, it was estimated that over 2.16 million episodes of typhoid occurred worldwide, resulting in 216000 deaths, and that more 
than $90 \%$ of this morbidity and mortality occurred in Asia[5]. Typhoid fever is endemic in all parts of Bangladesh and still constitutes a significant health hazard. The resistance of Salmonella enterica subspecies enterica serovar typhi ( $S$. Typhi) to chloramphenicol was first reported in India from Kerala, where a substantial outbreak took place in 1972. Since then multidrug-resistant strains of $S$. typhi have escalated into a worldwide problem. The steadily increasing multidrug resistance in $S$. typhi strains is a cause of grave concern in Bangladesh, where such strains are endemic in many parts [6]. Typhoid fever may occur at any age, but it is considered to be a disease mainly of children and young adults. In endemic areas, the highest rate occurs in children aged 8-13 years. In a recent study from slums of Delhi, it was found that contrary to popular belief, the disease affects even children aged one to five years. About 20-30\% of typhoid fever cases are children below ten years [3]. According to Indonesia Demographic and Health Survey $(2002$ - 03) report prevalence of typhoid fever in children under five years of age was $26 \%$ [8].

Human ABO blood group have been associated with susceptibility to certain infection[9,10]. It has been observed that some historical pandemics have influenced the current distribution of the $\mathrm{ABO}$ gene frequencies in different part of the world [11]. Various adaptations of people with different phenotypes of $\mathrm{ABO}$ blood group are considered to be the result of screening mutagens. Immunologists explain this by the presence of some pathogens of antigens similar to antigens of human blood [12].

During long-term observations it is found that the holders of blood groups $\mathrm{O}, \mathrm{A}, \mathrm{B}$, and $\mathrm{AB}$ have different predisposition to diseases. Statistical studies confirm that holders of blood group A get sick of viral hepatitis more often, and O-type people are less resistant to influenza virus[12]. According on the blood group, children under 7 years old usually get sick with diseases such as paratyphoid fever, rubella, scarlet fever, colibacillosis, and among children with blood group A it fails to develop immunity against smallpox even at re-vaccination[12].

So, there is a great need for the people to be aware of all the consequences of typhoid fever and it is the most important area where the health personnel should take serious measures to create an understanding and awareness among the public regarding typhoid fever and its risk factors. Typhoid fever continues to be a major health problem in Bangladesh. In the topical areas however, it is endemic in many places, due to the low standard of living, unprotected water supply and unhygienic methods in the preparation and handling of food. Many children with Typhoid fever are admitted in the hospital with various complications.
Few studies have been performed worldwide about these particular topics of Typhoid fever. But in Bangladesh such studies is practically absent. If these can be done then probably we will be able to increase the awareness about Typhoid fever so they may enjoy a good quality of life

\section{OBJECTIVES \\ General objective} in children.

To assess laboratory findings of typhoid fever

\section{Specific objectives}

To find out the socio-economic status of children with typhoid fever.

To assess the incidence of Typhoid fever among children of different age groups.

\section{Materials ANd Methods}

A case control study conducted in the Department of Paediatrics, Dhaka Shishu (Children) Hospital, Dhaka, Bangladesh during the period from October 2012 to April 2013. After getting written permission from the concerned authority of the selected Institute, the patients were approached. The study included children of paediatric age group both male and female. For each baby detailed history of age, sex, socio-economic information, and blood group were recorded. Subjects were grouped on the basis of age, sex, blood phenotypes, $\mathrm{ABO}$ and $\mathrm{Rh}$ into the case (Typhoid positive) and controls (Typhoid negative). Then assessed association between fever and socioeconomic, demographic and environmental conditions. 240 samples were purposively selected for the study which was divided into 120 cases and 120 controls. 1 to 18 years old children and toddlers were included in the study who were suffering from typhoid as case and suffering from any febrile illness, other than typhoid fever as control group. Participants suffered from meningitis, febrile convulsion, immunecompromised children, unwillingness to participate were excluded from the study. Prior to data collection, a questionnaire was designed for this study by reviewing all the available questionnaire of previous studies. The questionnaire was finalized following pretesting. Prior to answering the semi-structured questionnaire, every respondent had to undersign an informed written consent. All the data were collected and recorded systematically in a questionnaire and was analyzed using computer software SPSS (Statistical Package for Social Sciences).

\section{RESULTS}

This study was undertaken with the objective to assess the association between Typhoid fever and age, sex and blood phenotypes $\mathrm{ABO}$ and $\mathrm{Rh}$ group among children. A total of 240 children, out of whom 
120 were suffering from typhoid fever (cases) and 120 were non-typhoid (controls), were included in this study. The most of the caregiver of the children were female, $79.2 \%$ in cases and $68.3 \%$ in controls. $\chi 2=$ $3.069, \mathrm{df}=1, \mathrm{p}$-value $=0.07979854$; which means there are no any association between different gender groups. By age distributions of both groups were in the ' $\leq 5$ years' age group; $63.3 \%$ of Cases group and $80.8 \%$ of Controls group were in the age group. Mean \pm SD of age was calculated to be, $(5.1042 \pm 3.11575)$ for Cases group and for Controls group $(3.5951 \pm 2.50218)$. The p-value was 0.0001 for t-test and 0.01151045 for chisquare, which means there was an association in age distribution between the groups. $(p<0.05)$. It is illustrated that more than half of the participants in both Cases group [83 (69.2\%)] and Controls group [66 $(55.0 \%)]$ were Males. Male and Female ratio was about 2.25:1 in cases and 1.2:1 in controls. There might be a positive association between male gender and typhoid fever. Accordingly, the difference in male-female distribution between the groups was statistically significant $(\chi 2=4.284, \mathrm{df}=1 ; \mathrm{p}$-value $=0.03847271)$ $(\mathrm{p}<0.05)$ [Table 1]. It is illustrates that in a gross calculation, there was no statistically difference in distribution of $\mathrm{ABO}$ blood group of the children between cases and controls $(\chi 2=6.125 \mathrm{df}=3$; $\mathrm{p}$-value $=$
0.10568457). However, when each group was individually considered, blood group ' $\mathrm{B}$ ' indicated there may be some positive association with typhoid fever $[\mathrm{RR}=1.4505(95 \%$ CI: $1.0287-2.0452)$ and OR $=1.8713$ (95\% CI: $1.0565-3.3144)]$. The difference was statistically significant $\chi 2=4.66, \mathrm{df}=1 ; \quad \mathrm{p}$-value $=0.030873$. $(\mathrm{p}<0.05)$. [Table 2]. Only 3.3\% children in case group and $4.2 \%$ in control group had $\mathrm{Rh}$ negative blood group. There was no positive association $[\mathrm{RR} \quad=0.7857(95 \% \quad \mathrm{CI}: 0.1909-3.2341)$ and $\mathrm{OR}=0.7784(95 \%$ CI: $0.1791-3.3828$. Widal test result was positive in $83.3 \%$ of cases; the remaining $16.7 \%$ negative in case group and all $(100.0 \%)$ of the controls were found to be Widal negative in control group. The difference of Widal test result between the groups was statistically significant $\chi 2=18.22, \mathrm{df}=1$; $\mathrm{p}$ value $<.0001 .(p<0.05)$. Participants were included on the basis of their blood culture and/or Widal test findings; patients who had already done either one or both of the tests were considered for this study. Thus, blood culture was done in 50 (41.7\%) participants from the case group; out of them negative culture was obtained in $4(3.3 \%)$ individual and the remaining $46(38.3 \%)$ were culture positive. The difference was statistically significant $\chi 2=52.585$, $\mathrm{df}=2 ; \mathrm{p}$-value $=0 .(\mathrm{p}<0.05)[$ Table 3$]$.

Table-1: Demographic characteristics of the respondents $(n=240)$

\begin{tabular}{|c|c|c|c|c|}
\hline Respondents & Case (\%) & Control (\%) & $\chi^{2}$ & P-value \\
\hline Gender & & & \multirow[t]{3}{*}{3.069} & \multirow[t]{3}{*}{0.07979854} \\
\hline Male & 20.8 & 31.7 & & \\
\hline Female & 79.2 & 68.3 & & \\
\hline Age groups of the children & & & \multirow{4}{*}{$\begin{array}{l}4.009 \\
\text { (t-test) }\end{array}$} & \multirow[t]{4}{*}{0.0001} \\
\hline$\leq 5$ & 63.3 & 80.8 & & \\
\hline $5-10$ & 26.7 & 16.7 & & \\
\hline $10>$ & 10.0 & 2.5 & & \\
\hline Religion & & & \multirow[t]{4}{*}{1.709} & \multirow[t]{4}{*}{0.42549589} \\
\hline Muslim & 95.0 & 90.9 & & \\
\hline Hindu & 5.0 & 8.3 & & \\
\hline Others & 0 & 0 & & \\
\hline Educational status of the respondents & & & \multirow[t]{7}{*}{48.024} & \multirow[t]{7}{*}{0.0001} \\
\hline Illiterate & 4.2 & 0.8 & & \\
\hline Primary & 30.8 & 7.5 & & \\
\hline Secondary & 21.7 & 28.3 & & \\
\hline Higher secondary & 15.0 & 51.7 & & \\
\hline Graduate & 20.0 & 11.7 & & \\
\hline University & 8.3 & 0.0 & & \\
\hline Occupation of the respondents & & & \multirow[t]{4}{*}{10.676} & \multirow[t]{4}{*}{0.00480547} \\
\hline Job & 57.5 & 65.8 & & \\
\hline Business & 28.3 & 32.5 & & \\
\hline Others & 14.2 & 1.7 & & \\
\hline
\end{tabular}


Table-2: Laboratory findings of all study participants $(\mathrm{n}=\mathbf{2 4 0})$

\begin{tabular}{|c|c|c|c|}
\hline $\begin{array}{l}\text { Blood } \\
\text { Group }\end{array}$ & Cases $(n=120)$ Percent & $\begin{array}{c}\text { Controls } \\
(\mathrm{n}=120) \text { Percent }\end{array}$ & Statistical calculations \\
\hline $\mathrm{O}$ & 16.7 & 27.5 & $\begin{array}{l}\mathrm{RR}=0.6073 ; 95 \% \text { CI: } 0.3535-1.0433 \\
\mathrm{OR}=0.5285 ; 95 \% \text { CI: } 0.2665-1.0482 \\
\chi 2=3.39 ; \\
\mathrm{p} \text {-value }=0.065593\end{array}$ \\
\hline A & 25.0 & 25.0 & $\begin{array}{l}\mathrm{RR}=1.0 ; \quad 95 \% \text { CI: } 0.5272-1.6162 \\
\mathrm{OR}=1.0 ; \quad 95 \% \text { CI: } 0.6187-1.8967 \\
\chi 2=0.0 ; \\
\mathrm{p} \text {-value }=1.0\end{array}$ \\
\hline $\mathrm{B}$ & 48.3 & 33.3 & $\begin{array}{l}\mathrm{RR}=1.4505 ; 95 \% \text { CI: } 1.0287-2.0452 \\
\mathrm{OR}=1.8713 ; 95 \% \text { CI: } 1.0565-3.3144 \\
\chi 2=4.66 ; \\
\mathrm{p} \text {-value }=0.030873\end{array}$ \\
\hline $\mathrm{AB}$ & 10.0 & 14.2 & $\begin{array}{l}\mathrm{RR}=0.7042 ; 95 \% \text { CI: } 0.3293-1.5061 \\
\mathrm{OR}=0.6714 ; 95 \% \text { CI: } 0.2837-1.5889 \\
\chi 2=0.83 ; \\
\mathrm{p} \text {-value }=0.362273\end{array}$ \\
\hline
\end{tabular}

Table-3: Laboratory findings of all study participants $(n=240)$

\begin{tabular}{|c|c|c|c|}
\hline Blood group & $\begin{array}{c}\text { Cases } \\
(n=120) \\
\text { Percent }\end{array}$ & $\begin{array}{l}\text { Controls } \\
(n=120) \\
\text { Percent }\end{array}$ & Statistical calculations \\
\hline \multicolumn{4}{|c|}{ Rh typing of Blood } \\
\hline Positive & 96.7 & 95.8 & $\mathrm{RR}=0.7857 ; \quad 95 \% \mathrm{CI}: 0.1909-3.2341$ \\
\hline \multirow[t]{2}{*}{ Negative } & 3.3 & 4.2 & $\mathrm{OR}=0.7784 ; \quad 95 \% \mathrm{CI}: 0.1791-3.3828$ \\
\hline & & & $\begin{array}{l}\chi^{2}=0.112 \mathrm{df}=1 \\
\mathrm{p} \text {-value }=0.73787855\end{array}$ \\
\hline \multicolumn{4}{|l|}{ Widal Test } \\
\hline Positive & 83.3 & 0 & \multirow{2}{*}{$\begin{array}{l}\chi^{2}=18.22 \mathrm{df}=1 \\
\mathrm{p} \text {-value }=0.0001\end{array}$} \\
\hline Negative & 16.7 & 100 & \\
\hline \multicolumn{4}{|c|}{ Blood Culture } \\
\hline Not done & 58.3 & 100 & \multirow{3}{*}{$\begin{array}{l}\chi^{2}=52.585 ; \mathrm{df}=2 ; \\
\mathrm{p} \text {-value }=0.001\end{array}$} \\
\hline Positive & 38.3 & 0 & \\
\hline Negative & 3.3 & 0 & \\
\hline
\end{tabular}

\section{DiscUSSION}

This study was aimed to assess the association of Typhoid fever with age, sex and blood phenotypes $\mathrm{ABO}$ and $\mathrm{Rh}$ among children. A total of 120 cases (typhoid fever) and 120 controls (non-typhoid) were included in this study. In both groups most of the study participants were in the ' $\leq 5$ years' age group , Mean \pm SD of age was, $(5.1042 \pm 3.11575)$ for cases and for controls $(3.5951 \pm 2.50218), \mathrm{p}$-value was 0.0001 for t-test and 0.01151045 for chi-square, which means there was statistically deference in age distribution between the groups $(\mathrm{p}<0.05)$. A study in Dhaka Metropolitan Area found, the age-specific incidence rate was highest for the 0-4 years age group (277cases)[13]. More than half of the participants in both groups (69.2\% cases and 55.0\% controls) were Males. Male: Female ratio was about $2.25: 1$ in cases and $1.2: 1$ in controls.
There was positive association with male gender and typhoid fever $(\mathrm{RR}=1.2582$ and $\mathrm{OR}=1.8383)$. Accordingly, the difference in male-female distribution between the groups was statistically significant $(\chi 2=4.284, \mathrm{df}=1 ; \mathrm{p}$-value $=0.03847271) \quad(\mathrm{p}<0.05)$. Valenzuela CY and Herrera $\mathrm{P}[14]$ found a mild susceptibility to males. The male-female ratio of typhoid cases was found to be 1.36 by Dewan AM, Comer R, Hashizume M and Ongee ET[15], suggesting that in this population males are either more susceptible to typhoid, or more likely to present for hospital treatment, than females. Statistical differences of educational status of the respondent is significant $\chi^{2}=48.024, \mathrm{df}=5, \mathrm{p}$-value $=0.0001$. There was a statistically significant difference between the groups $(\chi 2=4.134, \mathrm{df}=2, \quad \mathrm{p}$-value $=0.04202989) \quad$ of occupational differences.. On gross calculation, there was no statistically difference in distribution of $\mathrm{ABO}$ 
blood group of the children between cases and controls $(\chi 2=6.125 \mathrm{df}=3$; p-value $=0.10568457)$. However, when each group was individually considered, blood group ' $\mathrm{B}$ ' indicated there may be some positive association with typhoid fever $[\mathrm{RR}=1.4505(95 \%$ CI: $1.0287-2.0452)$ and OR $=1.8713$ (95\% CI: $1.0565-$ $3.3144)]$. The difference was statistically significant $\chi 2=4.66, \mathrm{df}=1 ; \mathrm{p}$-value $=0.030873$. Valenzuela $\mathrm{CY}$ and Herrera $\mathrm{P}$ found that, the $\mathrm{B}$ allele conferred protection to females. Herrera $\mathrm{P}$ et al. [16]. Tested a hypothesis that blood phenotype $\mathrm{B}$ is associated to typhoid fever either directly or interacting with other phenotypes of the $\mathrm{Rh}$ or MNSs blood systems. Only $3.3 \%$ children in case group and $4.2 \%$ in control group had $\mathrm{Rh}$ negative blood group. There was no positive association [RR $=0.7857(95 \%$ CI: 0.1909 3.2341) and OR =0.7784 (95\% CI: 0.1791-3.3828)]; nor any statistically difference in distribution of the blood group of the children between cases and controls $(\chi 2=0.112 \mathrm{df}=1 ; \quad \mathrm{p}$-value $=0.73787855)$. Valenzuela CY and Herrera $\mathrm{P}$ reported the CDe haplotype (or the $\mathrm{RH} 3$ phenotype, mostly $\mathrm{CDe} / \mathrm{CDe}$ ) was associated with protection against Salmonella in both sexes, while cDE (or RH7, mostly cDE/cDE, and RH8, mostly cDE/cde) was associated with susceptibility to typhoid fever. Widal test result was positive in $83.3 \%$ of cases; the remaining $16.7 \%$ of cases and all $(100.0 \%)$ of the controls were found to be Widal negative. The difference of Widal test result between the groups was statistically significant $\quad \chi 2=18.22, \mathrm{df}=1 ; \quad \mathrm{p}$ value $<.0001$. Blood culture was done in $50(41.7 \%)$ participant from the case group; out of them negative culture was obtained in $4(3.3 \%)$ individual and the remaining $46(38.3 \%)$ were culture positive. The difference was statistically significant $\chi^{2}=52.585$, $\mathrm{df}=2 ; \mathrm{p}$-value $=0.001$.

\section{LiMitations OF THE STUDY}

This study was conducted in a tertiary care hospital with small sample size. So the study findings may not reflect the exact scenario of all around the country.

\section{CONCLUSION AND \\ RECOMMENDATIONS}

Risk of typhoid fever is higher in children aged $\leq 5$ years. Male are more susceptible to develop Typhoid fever. Accurate laboratory findings can give proper guideline for the treatment of the children and can give a real scenarios of health status of the children. Our study findings will contribute to improve child health in Bangladesh. We are recommending multicentre study with large sample size.

\section{REFERENCES}

1. Mrs RS. Tambulwadkar, "Paediatric nursing" Vora medical publications, 2nd edition, 108

2. Balentine JR. Typhoid fever. Available in [on line]: http://www.medicinenet.com/typhoid_fever/article. htm

3. Enteric fever. Textbook of Microbiology. Ananthanarayan and Paniker by Orient Blackswan; 7 th ed. $295-30$

4. Introduction of typhoid fever. Available in [on line]: http//www.google.com.

5. Park. "Text book of preventive and social medicine" Banarsidas Bhanot. 16th edition. 2000: 187

6. Crump JA, Luby SP, Mintz ED. The global burden of typhoid fever. Bull World Health Organ. 2004; 82: 346-53

7. Panikar CKJ, Vimala KN. Transferable chloramphenicol resistance in Salmonella typhi. Nature. 1972; 239:109-110

8. Etward J E, Nowesn J. Prevalence of typhoid fever in children; Journal of paediatrics; 2004.

9. Ratner JJ, Thomas VL, Roland IN. Relationship between human blood group, bacteria pathogens and urinary tract infections. The American J of Ned Sc. 1986; 292(2): 87-9.

10. Omoregie R, Ogufere HO, Omokaro EU, Omorogbe E. Distribution of $\mathrm{ABO}$ and Rhesus blood group and Haemoglobin phenotypes among Tuberculosis patients in Benin City - Nigeria J Med Lab Sc. 2000; 11(i): 68-70.

11. Issit DD and Anstee DJ. Applied blood group Serelogy. 4th Ad. Montgomem Scientific Public. 1996; 218-246.

12. Admin. Blood Group and Susceptibility to Diseases. URL: http://www.yourbtdiet.com/bloodtype-health/blood-group-and-susceptibility-todiseases/

13. Preventive aspects of Typhoid fever; Available in [on line] http//www.alldisease.com

14. Valenzuela CY, Herrera P. ABO, Rh, MNSs, sex and typhoid fever. Hum Hered. 1993 SepOct;43(5):301-10

15. Dewan AM, Comer R, Hashizume $M$ and Ongee ET. Typhoid Fever and Its Association with Environmental Factors in the Dhaka Metropolitan Area of Bangladesh: A Spatial and Time-Series Approach. PLoS Negl Trop Dis. 2013 January; 7(1): e1998.

16. Herrera P, Valenzuela CY. Study of the Widal test phenotypic expression of blood groups $\mathrm{ABO}, \mathrm{Rh}$ and MNSs in patients with typhoid fever. Rev Med Chil. 1992 Sep; 120 (9):994-7. 